\begin{tabular}{|c|c|c|}
\hline & International Journal of Current Research in & \\
\hline & Biosciences and Plant Biology & \\
\hline $\begin{array}{l}\text { DALLLLISHERS } \\
\text { PUBLISHER }\end{array}$ & $\begin{array}{c}\text { ISSN: 2349-8080 (Online) • Volume } 3 \bullet \text { Number } 4 \text { (April-2016) } \\
\text { Journal homepage: www.ijcrbp.com }\end{array}$ & \\
\hline
\end{tabular}

\title{
Study of Arsenic Impurity in Water of Lahore by Hydride Generation- Atomic Absorption Spectrophotometry
}

\author{
Irfana Mariam", Iram Khan², Sabeen Jaffar², Faiza Shahid², Islam-Ullah Khan², \\ Aminah Suhail Qureshi² and Ali Nawaz ${ }^{2 *}$ \\ ${ }^{1}$ Principal, Queen Mary College, 2-Durrand Road Garhi Shahu, Lahore, Pakistan \\ 'Institute of Industrial Biotechnology, Government College University Lahore, Lahore, Pakistan \\ *Corresponding author.
}

\begin{abstract}
A bstract
The aim of the research was to study the presence and to determine the level of arsenic impurity in Lahore's water by employing hydride generation-atomic absorption spectrophotometry. Water samples from different educational institutes of Lahore were collected, acidified, and subjected to analysis by HVG-FAAS. The study was conducted in the Department of Chemistry, Government College University Lahore between September 2013 and July 2014. The study included 18 samples which were subjected to HVG-FAAS analysis in order to determine the concentration of arsenic in terms of parts per billion (ppb). Out of 18 samples, 17 samples had arsenic concentration exceeding the limit defined by WHO (i.e., $10.0 \mathrm{ppb}$ ). Only 1 sample had the concentration of $8.0712 \mathrm{ppb}$, while 1 sample particularly exceeded the limit with a large margin by having the concentration of $24.2326 \mathrm{ppb}$. The concentration of arsenic needs to be controlled by employing both natural and anthropogenic methods in order to ensure the health of the denizens of Lahore. However, complete absorption of arsenic from water can result in chronic disorders. These predictors, however, need further work to validate reliability.
\end{abstract}

\section{Article Info}

Accepted: 15 March 2016

Available Online: 06 April 2016

\section{Keywords}

Arsenic impurity

Drinking water

Government educational institutes

HG-AAS

Lahore

\section{Introduction}

Exposure to pervasive trace element, Arsenic, proved to be lethal for local population (Morita and Kaneko, 2008). Toxicity of Arsenic is dependent on the concentration and form in which it exists. Inorganic Arsenic, usually present in water, is relatively more hazardous to the population. Organic Arsenic can be fatal only when exposed in high concentrations (Neha et al., 2013). Arsenic concentrations in air show an extensive range. Ranging from 0.02 to $4 \mathrm{ng} / \mathrm{m}^{3}$ in rural, 3 to about 200 $\mathrm{ng} / \mathrm{m}^{3}$ in urban and more than $1000 \mathrm{ng} / \mathrm{m}^{3}$ in industrial area (Luong et al., 2007).Studies revealed that the Center North of Burkina Faso has high concentration of Arsenic in water and its principle source of water supply is groundwater. A percentage of 11 drillings have shown high level of Arsenic crossing the standard limit of 10.0 $\mu \mathrm{g} / \mathrm{L}$ suggested by WHO. The highest rate of $22 \%$ has been found at Rouko commune (Espósito et al., 2011). Several analytical techniques, such as atomic fluorescence spectrometry (AFS), electro-thermal atomic absorption spectrometry (ETAAS), atomic absorption spectrometry (AAS), colorimetry, hydride generation system combined with atomic absorption spectrometry (HG-AAS) and inductively coupled plasma mass spectrometry (ICP-MS) are known for determination of arsenic. Previously, under ETAAS study, the dead biomass of Aspergillus niger applied on activated charcoal was used as a bioadsorbent and the effects of different parameters on bioadsorbent were examined 
(Shahlaei and Pourhossein, 2014). In ICP-MS, solid phase extraction cartridges were used for selective retention of arsenic. ICP-MS is a reliable method for detection and speciation of Arsenic (Watts et al., 2010). A report suggests that the concentration of Arsenic can also be calculated thermodynamically (Holm et al., 2004).

Molybdenum blue can also be used for the detection of arsenate. The reduction of arsenomolybdate produces the colour change and can be noticed at $870 \mathrm{~nm}$ wavelength (Some et al. 2014). A positive association between Arsenic level in drinking water and hair samples of female respondents has also been studied (Abbas and Cheema, 2014). HG-AAS is a highly sensitive technique to calculate the total amount of Arsenic in sample (Maria et al., 2013). For quantification, the water samples must have the same $\mathrm{pH}$ as of standard. In some cases the water samples may be treated with nitric acid to meet the standard. Sidhu et al. (2014) reported $0.68 \mu \mathrm{g} / \mathrm{L}$ as the quantification limit for Arsenic determination through HG-AAS. In the present study, the level of arsenic impurity in Lahore's water was studied by employing hydride generation-atomic absorption spectrophotometry.

\section{Materials and methods}

HG-AAS is most widely used technique for trace metal analysis. It is also known for determining the metal toxicity in soil, water and other biological samples. Hollow cathode lamp gives intense beam with constant light output. Hydride generation system uses liquid sample at a specific rate and blend it with sodium borohydride and hydrochloric acid which results in the formation of volatile hydride of the metalloid. Optical cell and flame converts the hydride form of Arsenic into elemental form. Monochromator detaches the line of photons from the light of other wavelengths. Photons emitted from the monochromator enter the Photomultiplier tube (PMT) for the detection of intensity. Thermal decomposition of Arsenic hydride was done and the absorbance was taken at $193.7 \mathrm{~nm}$.

Sample containers were thoroughly cleaned to avoid contaminants that may meddle with the target analyte. Here, the central chore is to find the presence of Arsenic in drinking water and its concentration level. Water samples of about $250 \mathrm{~mL}$ were collected from government institutions of Lahore in polyethylene vials. The vials were rinsed twice or thrice with the same sample water before the collection, as prescribed in previously published papers (Ulusoy et al., 2011). After collection, concentrated nitric acid was used to acidify the samples to $\mathrm{pH}$ below 2. Lowering the $\mathrm{pH}$ prevents precipitation and adsorption of heavy metals on the container walls. After acidifying, samples were kept in refrigerator at $4^{\circ} \mathrm{C}$ temperature (Song and Greg, 2007).

\section{Reagents and solutions}

Hydrochloric acid, nitric acid, sodium hydroxide and sodium tetrahydroborate were dissolved in distilled water; making up the total volume to $250 \mathrm{~mL}$. Standard solution of Arsenic was prepared in order to check the accuracy of the method. All the reagents used were of analytical grade.

\section{Sample collection}

The samples were collected from Government educational institutes of Lahore.

\section{Analysis by HVG-FAAS}

Samples were analyzed with SHIMADZU AA-7000 connected to HVG-FAAS. To generate gaseous hydride by peristaltic pump, the samples were introduced into a continuous flow of $30 \%$ hydrochloric acid and $0.25 \%$ sodium tetrahydroborate in a reaction coil. The arsine gas $\left(\mathrm{AsH}_{3}\right)$ was carried to the separator which separates the gas phase from liquid phase. The gas phase passed into the absorption cell while the liquid phase worn out. Absorption cell was heated by air acetylene flame to pyrolyze hydride to arsenic atoms (Ogbonna et al., 2011). Arsenic atoms were determined at $193.7 \mathrm{~nm}$ wavelength. The method is based on atomic absorption measurement of arsenic in drinking water generated by decomposition of arsenic hydride.

\section{Results and discussion}

Water samples collected from the Government educational institutes of Lahore showed arsenic impurities exceeding the limits set by WHO i.e., 10.0 $\mathrm{ppb}$. The concentration of Arsenic found in different samples is given in Table 1.

Concentration of arsenic observed in the samples from A to $\mathrm{J}$ were $13.6528 \mathrm{ppb}, 13.5718 \mathrm{ppb}, 12.3404 \mathrm{ppb}$, $15.3054 \mathrm{ppb}, 12.8670 \mathrm{ppb}, 14.9165 \mathrm{ppb}, 14.5196 \mathrm{ppb}$, $16.3909 \mathrm{ppb}, 14.3009 \mathrm{ppb}, 8.0712 \mathrm{ppb}, 14.7464 \mathrm{ppb}$, $12.7293 \mathrm{ppb}, 17.0633 \mathrm{ppb}, 24.2326 \mathrm{ppb}, 16.5529 \mathrm{ppb}$, $11.7815 \mathrm{ppb}, 11.6762 \mathrm{ppb}, 14.0740 \mathrm{ppb}$ respectively. Sample $\mathrm{N}$ had the maximum concentration of Arsenic, 
whereas, sample $\mathbf{J}$ indicates the safe concentration of Arsenic present in the drinking water. The contamination in water samples may be due to the borehole drilling or poor sanitary system. The underground water reservoirs may have Arsenic traces which later becomes the part of drinking water and proves fatal to life.

Table 1. Concentration of Arsenic in collected water samples.

\begin{tabular}{llll}
\hline Sr. No. & Samples & Absorbance & Concentration (ppb) \\
\hline 1 & A & 0.1615 & 13.6528 \\
2 & B & 0.1605 & 13.5718 \\
3 & C & 0.1453 & 12.3403 \\
4 & D & 0.1819 & 15.3054 \\
5 & E & 0.1518 & 12.8670 \\
6 & F & 0.1771 & 14.9165 \\
7 & G & 0.1772 & 14.5196 \\
8 & H & 0.1953 & 16.3909 \\
9 & I & 0.1695 & 14.3009 \\
10 & J & 0.0926 & 8.0712 \\
11 & K & 0.1750 & 14.7467 \\
12 & L & 0.1501 & 12.7293 \\
13 & M & 0.2036 & 17.0633 \\
14 & N & 0.2921 & 24.2326 \\
15 & O & 0.1973 & 16.5529 \\
16 & P & 0.1384 & 11.7815 \\
17 & Q & 0.1371 & 11.6762 \\
18 & R & 0.1667 & 14.0740 \\
\hline
\end{tabular}

\section{Conclusion}

The conducted research expose that water in certain areas of Lahore has greater concentration of Arsenic than the standard value that is $\leq 10.0 \mathrm{ppb}$. Except sample $\mathrm{J}$ (with $8.0712 \mathrm{ppb}$ ), all the other institutions have unhealthy drinking water. The samples were particularly tested for the existence of Arsenic in drinking water of Lahore, only. $88.88 \%$ of the sampleswere found contaminated with this hazardous metalloid. Highest level of Arsenic was detected $24.2326 \mathrm{ppb}$ in sample N. Poor sewage system is one of the causes of water contamination. Domestic waste has badly affected the water quality of this area. Due to interconnection of WASA tube wells, dilution could take place which lower the level of arsenic in the system caused by any particular tube well. The Water and Sanitation department has started digging the deep-wells to ensure supply of clean water to the citizens. However, the old water pipes have made this practice futile. The other causes of contamination may include raw sewage irrigation, land disposal of industrial effluents and the use of deep soakage pits and excessive aid of fertilizers and pesticides.

Thousands of people in Lahore are facing this alarming situation. The quantity of Arsenic in ground water must be controlled by both natural and anthropogenic processes. Complete absorption of arsenic from water can cause acute as well as chronic disorders (e.g. hypertension, cancer, poly-neuropathy, tingling sensation, cardiovascular diseases, etc.).

\section{Conflict of interest statement}

Authors declare that they have no conflict of interest.

\section{Acknowledgement}

Authors are acknowledging the cooperation and support of co-workers and different Government educational institutes of Lahore. Special thanks to Government College University for providing the laboratory facilities to accomplish this chore.

\section{References}

Akbar Abbas, M., Cheema, K.J., 2014. Correlation Studies of Arsenic Level in Drinking Water and hair Samples of Females in District Sheikhupura, Pakistan. Int. J. Curr. Microbiol. App. Sci. 3, 1077-1085.

Esposito, M.E., Paoloni, J.D., Sequeira, M.E., Amiotti, N.M., Del, M., Blanco, C. 2011. Natural contaminants in drinking waters (arsenic, boron, fluorine and vanadium) in the Southern Pampean plain. J. Environ. Prot. 2, 97-108.

Holm, T.R., Kelly, W.R., Wilson, S.D., Roadcap, G.S., Talbott, J.L., Scott, J.W., 2004. Arsenic Geochemistry and 
Distrbution in the Mahomet Aquifer, Illision. Illinois Waste Management and Research Center.

Luong, J.H.T., Majid, E., Male, K.B., 2007. Analytical tools for monitoring arsenic in the environment. J. Open Anal. Chem. 1, 7-14.

Maria, G.C., Balalau, D., Mihaela, I., Nicoleta, P.C., Miriana, G., 2013. Quantitative determination of arsenic in bottled drinking water using Atomic Absorption Spectroscopy. J. Acta Medica Marisiensis. 59, 246-249.

Morita, K., Kaneko, E., 2006. Determination of arsenic in water samples based on micro particle formation of ethyl violet-molybdoarsenate. Anal. Sci. 22(8), 1085-1089.

Neha, C., Pandey, S.K., Devendra, M., 2013. Determination of arsenic content in the water and blood samples of Ballia region using Hydride Generation Atomic Absorption Spectrophotometer. J. Forensic Sci. 1, 1-3.

Ogbonna, O., Jimoh, W.L., Awagu, E.F., Bamishaiye, E.I., 2011. Determination of some trace elements in water samples within Kanometropolis. Adv. Appl. Sci. Res. 2, 62-68.

Shahlaei, M., Pourhossein, A., 2014. Determination of arsenic in drinking water samples by Electrothermal Atomic Absorption Spectrometry after preconcentration using the biomass of Aspergillus niger loaded on activated charcoal. J. Chem. 2014 (2014), Article ID 912619, 6 p.

Sidhu, M., Mahajan, P., Bhatt, S.M., 2014. Highly sensitive and low cost colorimetric method for quantifying arsenic metal in drinking water of Malwa Punjab and comparison with ICAP-AES. Ann. Biol. Res. 5, 105-109.

Some, T.I., Sakira, A.K., Kabore, A., Traore, A., 2014. A survey of arsenic level in tube-wells in Bam Province. J. Environ. Prot. 5, 1406-1410.

Song, Y., Greg, M.S., 2007. Total inorganic arsenic detection in real water samples using anodic stripping voltammetry and a gold-coated diamond thin-film electrode. J. Anal. Chim. Acta. 593, 7-12.

Ulusoy, I.H., Akcay, M., Gurkan, R., 2011. Determination of ultra-trace arsenic species in water samples by hydridegeneration atomic absorption spectrometry after cloud point extraction. J. Anal. Chim. Acta. 703, 137144.

Watts, M.J., Reilly, J.O., Marcilla, A.L., Shaw, R.A., Ward, N.I., 2010. Field based speciation of arsenic in UK and Argentinean water samples. J. Environ. Geochem. Health. 32, 479-490.

\section{How to cite this article:}

Mariam, I., Khan, I., Jaffar, S., Shahid, F., Khan, I. -U., Qureshi, A. S., Nawaz, A., 2016. Study of arsenic impurity in water of Lahore by Hydride Generation-Atomic Absorption Spectrophotometry. Int. J. Curr. Res. Biosci. Plant Biol. 3(4), 1-4. doi: http://dx.doi.org/10.20546/ijcrbp.2016.304.001 